\title{
Diagnosis and Treatment of Xerostomia
}

\author{
Jeong-Seok Choi and Jae-Yol Lim \\ Department of Otorhinolaryngology-Head and Neck Surgery, Inha University School of Medicine, Incheon, Korea
}

\section{구강건조증의 진단과 치료}

\author{
최 정 석·임 재 열 \\ 인하대학교 의과대학 이비인후과학교실
}

\author{
Received March 1, 2016 \\ Revised March 25, 2016 \\ Accepted April 15, 2016 \\ Address for correspondence \\ Jae-Yol Lim, MD, PhD \\ Department of Otorhinolaryngology- \\ Head and Neck Surgery, \\ Inha University School of Medicine, \\ 27 Inhang-ro, Jung-gu, \\ Incheon 22332, Korea \\ Tel $+82-32-890-3570$ \\ Fax $+82-32-890-3580$ \\ E-mail jylim@inha.ac.kr
}

Xerostomia is a subjective sensation of a dry mouth which is frequently encountered in otorhinolaryngologic practice. There are a variety of salivary and nonsalivary causes of xerostomia such as side effects of medication, systemic disorders, radiation and Sjögren's syndrome. The patients with xerostomia have difficulties in chewing, swallowing, speaking, tasting and mataining oral hygiene. Because of the ageing population, and the concomitant increase in medicated individuals, otorhinolaryngologists can expect to be presented with xerostomia in an increasing number of patients in the coming years and therefore should be familiar with its diagnosis and treatment. A systematic approach should be needed to determine the etiology of xerostomia and the management of xerostomia should be multidisciplinary and multimodal. This review summarizes the current literature on the diagnosis, and complications of xerostomia, and on the management of patients with xerostomia.

Korean J Otorhinolaryngol-Head Neck Surg 2016;59(6):424-9

Key Words Dry mouth $\cdot$ Saliva $\cdot$ Salivary hypofunction $\cdot$ Xerostomia.

\section{서 론}

구강건조증(xerostomia)은 입이 마른다고 느끼는 주관적 인 증상을 일반적으로 의미한다. ${ }^{1)}$ 구강건조증은 객관적인 타 액분비의 저하가 관찰되지 않더라도 생길 수 있으며, 타액의 성분에 변화가 있어도 그 증상이 유발된다고 알려져 있다. ${ }^{2)}$ 일반적으로 성인은 하루에 1 1.5 L의 타액이 분비되며, 정상 적인 타액의 양은 자극이 없을 때는 분당 $0.3 \sim 0.4 \mathrm{~mL}$, 자극 이 있을 때는 분당 $1.5 \sim 2.0 \mathrm{~mL}$ 가 분비되어야 한다. ${ }^{3)}$ 통상적 으로 타액의 분비가 $50 \%$ 이상 감소된 환자의 경우 구강건조 증의 증상이 나타난다고 알려져 있다. 또한 입으로 숨을 쉬면 서 입 안의 수분이 증발되면 주관적으로 구강의 건조함을 느 낄 수 있다. 타액분비의 저하를 가지고 있는 구강건조증 환자 들은 구강점막에서 흡수되는 타액의 양과 구강에서 증발되 는 타액의 양을 합친 것보다 타액이 적게 분비될 때 보통 진 단이 되는 것으로 알려져 있다. ${ }^{4)}$ 그러나, 통상적으로 자극 시
분당 05 0.7 mL 이하 또는 비자극 시 분당 $0.1 \mathrm{~mL}$ 이하의 타액이 분비되는 경우에 타액분비저하증(hyposalivation)으 로 정의한다. ${ }^{3)}$

구강건조증을 가진 환자들은 말을 하거나 음식을 먹을 때 어려움을 호소하며, 타액의 분비가 적은 구강건조증 환자의 경우에는 충치나 세균감염, 미각의 변화, 구취, 구강의 작열감 과 같은 증상을 호소하기도 한다. ${ }^{5)}$ 또한 노인의 경우 구강 위 생 악화, 연하 장애 등으로 인한 오연성 폐렴 등과 같은 전신 질환에 이환될 위험성도 높아지는 것으로도 알려져 있다. ${ }^{6}$ 구강건조증의 유병률은 0.9 64.8\%로 매우 다양하며," 65 세 이상의 인구에서 $30 \%$ 정도가 구강건조증을 가지고 있는 것 으로 보고되었다. ${ }^{8)}$ 쇼그렌 증후군(Sjögren's syndrome)이나 두경부 종양으로 방사선 치료를 받은 환자들의 구강건조증 유병률은 거의 $100 \%$ 에 이른다고 알려져 있다. ${ }^{9,10}$

구강건조증을 일으키는 원인으로는 매우 다양한 인자가 알려져 있다. 생리적인 탈수나 신경학적, 인지기능의 이상이 있 
을 경우에 구강건조증이 생길 수 있으며, 우울증이나 불안장 애 및 스트레스와 같은 감정의 변화나 영양장애가 있을 때에 도 구강건조증이 나타나기도 한다. 구강건조증의 가장 흔한 원인 중의 하나는 약물의 복용이다. 항응고제, 항우울제, 항 고혈압제, 항바이러스제, 당뇨치료제 등이 구강건조증을 유 발하는 흔한 약물로 알려져 있으며, 쇼그렌 증후군을 않거나 두경부 영역의 방사선 치료를 받은 경우에 유발되기도 하 며, ${ }^{11)}$ 전신질환이나 타액선의 외상 및 종양에 의해서도 유발 될 수 있다(Fig. 1).

본 논문은 최근 증가하고 있는 구강건조증 환자를 이해하 고 구강건조증을 진단하기 위한 체계적인 접근과 다양한 치 료법에 대한 최신 지견을 정리하여 소개하고자 한다.

\section{본 론}

\section{구강건조증의 진단}

\section{구강건조증 관련증상}

구강건조증이나 타액분비저하증을 진단하기 위해서는 체 계적인 접근이 중요하다. 먼저, 환자의 주관적인 증상에 대해 관심을 기울이고 이를 의학적으로 상세히 확인하는 과정이 필요하다. 왜냐하면 환자의 특정 증상은 환자의 타액분비저 하나 구강건조증의 증상을 예측하는 데 중요한 단서가 될 수 있기 때문이다. 가령 식사를 할 때 구강의 건조함이 느껴지거 나, 마른 음식을 먹을 때 물이 반드시 필요한 경우, 연하 시 불 편감을 느끼는 증상들은 실제 타액분비의 저하가 동반될 가 능성이 높다. 그러나, 객관적인 타액분비의 저하가 없더라도 구강건조증의 불편감은 환자에게 일어날 수 있다. ${ }^{12)}$ 이외에도 말을 하는 데 불편하거나 미각의 변화, 입안의 작열감, 구취 등의 증상이 유발될 수 있으며, 의치를 가지고 있는 환자는 이를 조작하는 데 있어 어려움을 느낄 수 있다. 환자의 자세 한 병력과 복용하는 약물을 확인하는 것은 반드시 필요한 절

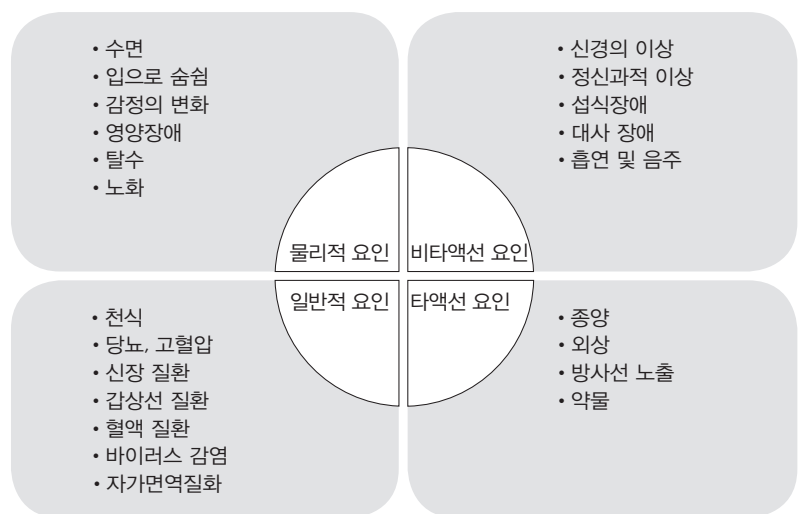

Fig. 1. Various causes of xerostomia.
차 중의 하나이다.

\section{구강건조증의 증상에 관한 설문}

구강건조증을 확인하기 위해 다양한 기관에서 이에 관련된 설문지들이 개발되었는데, Sreebny와 Valdini ${ }^{13}$ 에 의하면 설 문지 문항 중 “입이 항상 마른 감이 든다”의 문장 하나로도 타 액분비저하를 예측하는데, 민감도 $93 \%$, 특이도 $68 \%$ 를 보인다 고 알려져 있다(Table 1). 구강건조증 및 타액분비저하증의 가 장 중요한 요소 중의 하나가 약물이다(Table 2). 또한 약물의 복용량이 많을수록 구강건조증과 타액분비저하증에 많은 영 향을 준다고 알려져 있다. ${ }^{14)}$ 정신과 약물, 당뇨치료제, 호흡기 약물, 항고혈압제 등과 같은 다양한 약물들의 복용여부를 확 인하여야 한다. ${ }^{15)}$ 이외에도 구강건조증을 일으킬 수 있는 쇼그 렌 증후군, 방사선 치료 여부, 고혈압, 천식, 당뇨, 혈액질환, 갑 상선질환, 류머티즘 질환, 정신과 병력 등을 확인하여야 한다.

\section{구강 검진}

타액분비의 저하나 구강건조증을 유발할 수 있는 구강의 이상이나 구강 이외의 신체검사는 반드시 필요한 절차이다. Osailan 등흐은 구강의 점막이 끈적하고, 타액에 거품이 많으 며, 구강저에 타액의 저류가 보이지 않고, 혀의 미뢰가 많이 소 실되고, 잇몸이 위축되고 구개의 점막이 미끈하게 보이며, 혀 가 갈라지고 충치 및 점막의 지저분한 분비물이 관찰되는 것

Table 1. Various questions to diagnose xerostomia and hyposalivation

\section{설문 문항}

1. 나는 말을 할 때 입안의 건조함을 느낀다.

2. 나는 음식을 씹을 때 입안의 건조함을 느낀다.

3. 나는 식사를 할 때마다 입안의 건조함을 느낀다.

4. 나의 입은 현재 건조한 느낌이 든다.

5. 나는 밤에 자다가 물을 마시기 위해 일어난다.

6. 나는 음식을 삼키기 위하여 물을 마신다.

7. 나는 평상시에도 입안의 건조함을 줄이기 위해 물을 마신다.

8. 나는 마른 음식을 먹을 때 어려움이 있다.

9. 나는 단단한 음식을 삼키는데 어려움이 있다.

10. 나는 입의 건조함을 줄이기 위해 사탕과 같은 단 것을 먹는다.

11. 나는 잇몸염증이나 충치로 치과를 방문한다.

12. 나는 귀아래(뺨)나 턱 밑이 아프다.

13. 나는 귀아래(뺨)나 턱 밑이 붓는다.

14. 나는 혀가 아프거나 화끈거린다.

15. 나는 입에서 좋지 않은 냄새가 난다.

16. 나는 목이 아프다.

17. 나는 목이 쉬거나 목소리가 변한다.

18. 나는 혀로 느끼는 맛의 변화가 있다.

19. 나의 입술 주위가 헌다.

20. 나는 입술이 자주 마른다.

21. 나는 코가 자주 마른다. 
이 타액분비저하를 진단하는 데 도움이 된다고 하였다(Fig. 2). 그러나 이러한 구강 소견과 환자의 증상과의 상관관계는 반드 시 일치하지는 않는다.

\section{타액분비량의 측정}

타액분비량의 측정은 구강건조증의 원인이 타액선에 있는 지 다른 부분에 있는지를 알기 위해 필수적인 검사법이다. 타 액분비량의 측정은 방법이 쉽고 검사시간이 짧아야 한다. 타 액분비량은 적어도 5 분 이상 측정하는 것이 보통이며, 다른 혼란 변수를 배제하기 위해 보통 2시간 이상의 금식 후에 측

Table 2. Classificaion of various drugs causing xerostomia

\begin{tabular}{|c|c|}
\hline 약물분류 & 약물 소분류 \\
\hline 항콜린성 약물 & $\begin{array}{l}\text { Tricyclic antidepressants } \\
\text { Antipsychotics } \\
\text { Anticonvulsants } \\
\text { Antiparkinsonian drugs } \\
\text { Anti-reflux agent } \\
\text { Antiemetics } \\
\text { Antihistamines } \\
\text { Drugs for urinary incontinence } \\
\text { Bronchodilators }\end{array}$ \\
\hline 교감신경자극 약물 & $\begin{array}{l}\text { Antidepressant } \\
\text { Appetite suppressants } \\
\text { Decongestants } \\
\text { Beta-agonists bronchodilators } \\
\text { Skeletal muscle relaxants } \\
\text { Amphetamines }\end{array}$ \\
\hline 항고혈압제 & $\begin{array}{l}\text { Angiotensin converting enzyme inhibitors } \\
\text { Angiotensin ii receptor antagonists } \\
\text { Calcium channel blockers } \\
\text { Alpha adrenergic blockers } \\
\text { Beta adrenergic blockers } \\
\text { Alpha2 agonists } \\
\text { Diuretics }\end{array}$ \\
\hline \multicolumn{2}{|l|}{ 항암제 } \\
\hline \multicolumn{2}{|l|}{ 항바이러스제 } \\
\hline \multicolumn{2}{|l|}{ 아편제제 } \\
\hline \multicolumn{2}{|l|}{ 편두통 약물 } \\
\hline \multicolumn{2}{|l|}{ 마약성 진통제 } \\
\hline \multicolumn{2}{|c|}{ 과민성 장증후군 치료제 } \\
\hline 진정제 & \\
\hline
\end{tabular}

정을 한다. 대부분은 앉은 자세로 타액의 분비량을 측정하며 미리 준비한 기구에 타액을 모으거나 무게를 미리 잰 솜을 구강에 넣어 타액을 모은 후 무게를 측정하여 타액분비량을 측정하기도 한다. 솜을 넣는 위치는 타액이 분비되는 입구나 구강저에 위치하도록 한다. 타액분비량은 자극을 주지 않고 타액분비량을 측정(unstimulated salivary flow rate)하는 방 법과 저작을 통한 타액분비의 자극을 주거나 타액의 분비를 촉발하는 구연산, 비타민 C 등을 준 후에 타액의 분비량을 측 정(stimulated salivary flow rate)하는 방법이 있으며, 대부분 은 이 두 가지 방법을 같이 측정한다. 타액분비량은 특정 시간 동안 배출되는 타액의 총 무게를 시간(분)으로 표시하게 되며 타액의 비중은 1 이므로 무게는 부피로 바로 환산하여 타액의 분비량을 측정할 수 있다. 경우에 따라서는 특별히 고안된 기 구나 피펫, 페이퍼 패취 등을 이용하여 특정한 타액선의 타액 분비량을 따로 측정하기도 한다. ${ }^{17)}$

\section{타액선 기능검사}

타액선 기능은 타액선 섬광조영술(salivary scintigraphy)을 통해서도 측정할 수 있다. 테크네슘 ${ }^{99 \mathrm{~m}}$ technetium pertechnetate)을 투여한 후 타액선에 흡수된 테크네슘의 양과 타액을 분비시킨 후 타액선에 남은 테크네슘의 양을 측정하여 타액선 의 흡수율과 배출율을 측정하여 타액선의 기능을 확인할 수 있다. 이외에 자기공명 영상(magnetic resonance imaging)이 나 컴퓨터단층촬영(computer tomography)과 같은 영상학적 검사를 통해서도 타액선의 기능을 확인할 수 있으며 이는 타 액선 실질의 이상을 관찰하는 데 유용하다. 초음파(ultrasonography) 역시 타액선의 실질이나 그 주변을 비침습적으로 관 찰하는 데 유용한 방법이다. 타액선 조영술(sialography)은 타 액선관의 입구에 방사성 비투과성 물질을 주입하여 타액선관 의 해부학적 구조나 타액선 세포의 상태 및 타석, 종양 등을 관찰하는 데 유용하다. 최근에는 타액선 조영술을 대신하여 자기공명 타액선 조영술(MR sialography)이 시행되기도 하는 데, 이는 타액선의 실질과 관의 형태를 확인하고 타액을 조영 제로 하여 타액선의 기능도 확인할 수 있는 이점을 가지고 있
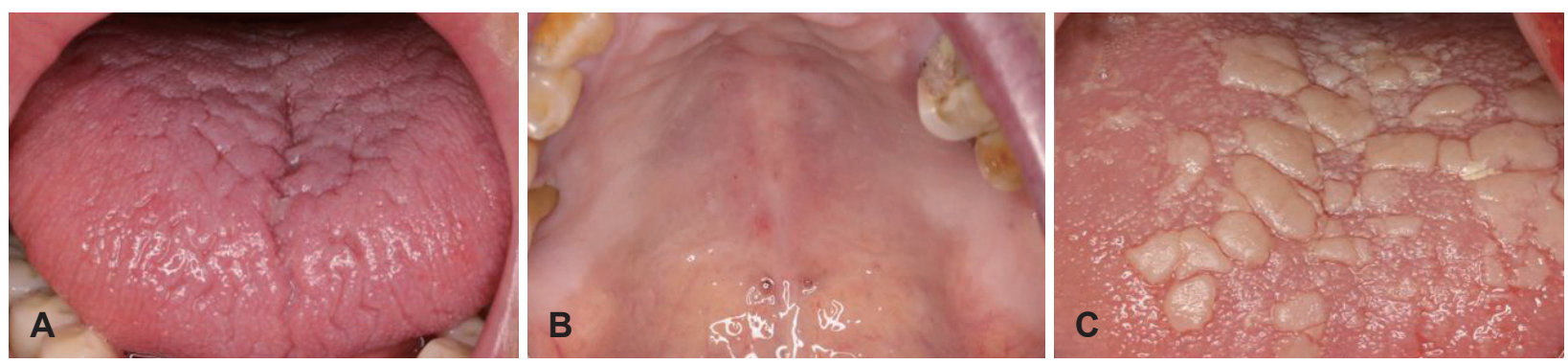

Fig. 2. Clinical findings of patients with xerostomia (hyposalivation). Fissured tongue and scanty saliva pooling in floor of mouth (A). Glassy appearance of oral mucosa (B). Mucous debris and fungal infection (C). 
다. ${ }^{18)}$ 자기공명 타액선 조영술은 자기공명 담췌관 조영술과 같 은 원리로, 긴 T2 이완 시간(T2 relaxation times)과 긴 에코시 간(echo tomes)을 통하여 기존 T2 강조영상(T2-weighted image)에서 보다 정적이거나 거의 정적인 상태의 유동체를 더 강조하여 영상을 얻게 되며 위 영상을 삼차원(3-dimensional) 으로 재건하여 타액선관의 형태학적인 구조를 평가할 수 있어 타석증, 타액선관의 협착 및 폐쇄에 대한 진단에도 도움을 준 다. ${ }^{19}$ 쇼그렌 증후군의 진단을 위해 입술에 있는 소타액선을 얻어 조직검사를 시행하기도 하며, 정확한 타액선의 진단을 위 해 미세침 흡인검사(fine-needle aspiration)를 시행하기도 한다(Table 3).

\section{구강건조증의 치료}

구강건조증은 단 하나의 치료로 증상을 완화할 수 있는 충 분한 근거가 없기 때문에 여러 가지의 치료법을 선택하여 가 장 효과가 좋을 방법을 선택하는 것이 좋으며, 단계적으로 치 료하는 것이 필요하다(Table 4).

구강건조증을 치료하기 위한 다양한 치료전략들이 연구되 고 있는데, 일차적인 목적은 환자의 증상을 줄이고, 타액의 분 비량을 늘리는 것이다. 가장 쉬운 방법 중의 하나는 적절한 수 분을 공급하고, 구강건조증을 악화시킬 수 있는 치약이나 음 식물 섭취 등을 자제하며, 저작 및 타액분비에 도움을 주는 무설탕 껌 등의 사용이다. ${ }^{20)}$ 이외에도 구강 점막에 윤활제나 타액 성분의 대체제, 타액선 자극제 등의 사용도 증상의 경감 에 도움이 될 수 있다.

\section{전신 타액분비 촉진제(Systemic sialogogues)}

필로카르핀(Pilocarpine)과 세비멜린(Cevimeline)은 미국

Table 3. Evaluation of xerostomia and hyposalivation

\begin{tabular}{ll}
\hline \multicolumn{1}{c}{ 평가 요소 } & \multicolumn{1}{c}{ 평가방법 } \\
\hline 과거력 & 전신질환 확인 \\
& 외상 유무 \\
& 약물 \\
설문 & 구강건조증, 타액분비 저하 확인 \\
신체검사 & 구강검진 \\
& 구강 외 검진 \\
& 타액분비량 측정 \\
& 자가면역 관련 인자 \\
혈액검사 & Complete blood count with differential \\
& serum immunoglobulins, \\
& erythrocyte sedimentation rate \\
& 타액선 조영술 \\
& 타액선 섬광조영술 \\
타액선 영상 & 컴퓨터단층촬영, 자기공명영상, 초음파 \\
& 자기공명 타액선 조영술 \\
& 소타액선 \\
& 미세침 흡인검사 등 \\
\hline
\end{tabular}

식품의약국 $(\mathrm{FDA})$ 의 승인을 받은 타액분비 촉진제이다. 필로 카르핀은 무스카린(muscarine)의 부교감신경을 자극하고, 세 비멜린은 M3 무스카린 수용체와 강한 친화력을 보이는 타액 선 자극제로 알려져 있다. 필로카르핀은 쇼그렌 증후군과 방 사선 조사에 의한 구강건조증 치료제로 승인되었으며, 세비멜 린은 쇼그렌 증후군의 치료에 승인이 되었다. 이러한 약물들은 기능을 하는 타액선의 잔여조직이 남아 있어야 효과적일 수 있다. 이 두 약물은 구강건조증을 지닌 환자에 비슷한 효과를 나타낸다. 필로카르핀은 5 밀리그램, 세비멜린의 경우 30 밀리 그램의 용량을 하루 세 번 복용하며, 적어도 3 개월 이상 사용 하는 것을 원칙으로 한다. 21,22$)$ 필로카르핀을 입을 헹구는 데 사용할 경우에도 타액의 분비가 증가되며 주관적인 증상이 호전된다는 보고도 있다. ${ }^{23)}$ 필로카르핀의 부작용이 나타날 수 있으며 땀 분비의 증가, 피부 혈관의 확장, 오심 및 구토, 설사, 딸꾹질, 기관지 축소, 저혈압, 빈맥, 증가된 빈뇨, 시야의 이상 등을 초래할 수 있다. 필로카르핀과 세비멜린은 조절이 되지 않는 천식환자나 만성폐질환, 베타 차단제를 사용하고 있는

Table 4. Treatment of xerostomia and hyposalivation

\begin{tabular}{clc}
\hline 치료요소 & \multicolumn{1}{c}{ 치료법 } & 효과 \\
\hline 생활환경 개선 & 잦은 수분의 공급 & \\
& 마르고 딱딱한 산성음식 제한 & \\
& 카페인, 알코올 함유 & \\
& 음료의 제한 & \\
& 가습기 사용
\end{tabular}

전신질환 다학제적 기저질환의 관리

타액분비자극제 약물 용량의 조절 및 변경

$\begin{array}{lll} & \text { 세비멜린 } & \\ & \text { Anethole trithione } & \\ & \text { Yohimbine } & \\ & \text { Anticholinesterase } & \\ & \text { physostigmine } & \\ \text { 타액 대체제 } & \text { 인공 타액 } & \text { 타액의 점성 증가 } \\ \text { 및 윤활제 } & \text { 헹굼제 } & \text { 타액의 천연성분 모사 } \\ & \text { 젤, 스프레이 } & \text { 타액분비증가는 없음 } \\ & \text { 치약 } & \\ \text { 저작운동 } & \text { 무설탕 껌 } & \text { 타액분비의 증가 } \\ & \text { 무설탕 사탕 } & \text { 점막의 마찰 감소 } \\ \text { 타액선 자극 } & \text { 전기 자극 } & \text { 증상의 경감 } \\ & \text { 침을 통한 자극 } & \text { 타액분비의 증가 } \\ \text { 충치예방/보철물관리 불소의 사용 } & \\ & \text { 보철물 소독(chlorhexidine) } \\ & \text { 보철물 유착제 사용 } & \\ & \text { 정기적인 검진 및 관리 } & \\ \text { 구강 내 장치 } & \text { 나이트 가드(night guard) } & \text { 타액분비의 증가 } \\ & & \text { 타액의 증발 예방 } \\ \text { 세균 및 곰팡이 } & \text { 항생제의 사용(7-10일) } & \\ \text { 감염예방 } & \text { 항진균제 사용 } & \\ \text { 재생의학 } & \text { 줄기세포 } & \\ & \text { 성장인자 } & \\ & \text { 항산화제 함유 천연물질 } & \\ & & \end{array}$


환자에게 상대적으로 금기가 되며, 급성 위궤양이나 조절되지 않은 고혈압 환자들에게 조심스럽게 사용되어야 한다. 필로카 르핀은 협각 녹내장이나 홍채염 환자에게 또한 금기가 될 수 있다. Anethole trithione은 담즙배출 촉진제로서 구강건조의 증상을 완화시키고 타액의 분비를 촉진시킨다고 알려져 있으 나 아직 더 많은 연구가 필요하다.24)

\section{국소적 약제들(Intraoral topical agents)}

구강 내에 국소적으로 분무하는 약제들은 구강건조증 환자 들에게 가장 많이 사용되는 약제이다. 저작을 위한 껌, 타액선 분비자극제, 타액 대체제 등이 여기에 포함된다. 국소 분무약 제에 포함되는 말산(malic acid)을 포함한 약제가 많은데 이 는 항우울제나 항고혈압제를 사용하는 구강건조증 환자의 증 상을 경감하는 데 효과적이라고 알려져 있다. 25,26$)$ 그러나 말산 이 치아의 에나멜을 부식시킬 수 있음으로 사용에 유의하여 야 한다. 상업적으로 유용한 무설탕 껌이나 사탕의 경우도 타 액의 분비를 촉진하기 위해 사용된다. 무설탕 껌은 타액의 분 비를 증가시킴은 물론 구강점막의 마찰을 감소시켜 주는 부가 적인 역할도 한다. 무설탕 껌 외에도 타액선 자극제나 대체제 (젤, 치약, 입안 헹굼제, 스프레이)도 많이 사용되는 약물이다. 타액 대체제는 점도를 증가시키고 타액분비량을 변화시키 지 않고 자연스런 타액의 성분을 모방하는 데 목적을 둔다. 이 러한 약물은 불소, 칼슘, 인과 같은 미네랄과 carboxymethylcellulose나 hydroxyethylcellulose, 착향제 및 보존제 등을 포 함하고 있다. ${ }^{20)}$ 상품 중에는 올리브 오일이나 베타인(betaine), 자일리톨 등이 포함된 타액 대체제도 있으며, glycerol triester 를 함유한 구강 스프레이 역시 타액선 대체제로서 효과적인 약물로 알려져 있다. ${ }^{27)}$ 이외에도 지방 성분의 점막 보존제나 뮤신(natural mucins), 점액성 다당류(mucopolysaccharide)가 함유된 스프레이 등이 사용되기도 한다. 그러나, 이러한 대부 분의 타액 대체제는 타액의 분비를 증가시키지는 않는다고 알 려져 있다. ${ }^{28)}$ 최근에는 젤 형태로 만들어진 구강의 윤활제도 개발, sodium lauryl sulfate와 osmoprotectant(glycine betaine) 등을 포함한 합성 계면활성제가 포함된 치약, 무수화된 말토스(maltose)의 복용이나 항콜린에스터라제(anticholinesterase)인 physostigmine의 구강건조증에 대한 효과도 연구되 고 있다.

\section{기타(Others)}

비록 증거가 부족하기는 하지만 구강건조증을 유발하는 약 제의 용량을 줄이거나 다른 약물로 대체하는 방법이 쓰이기 도 한다. ${ }^{29}$ 그러나 이는 환자가 앓고 있는 질환을 담당하는 의 사와 반드시 상의하여 결정하여야 한다.
구강의 전기 자극을 통해 타액 분비를 증가시키려는 일부 의 연구도 시도되고 있다. ${ }^{30}$ 타액 분비의 자극을 위해 Saliwell Crown, electrostimulating device GenNarino 등의 구강 내 장치가 연구되었으며,1) 침(acupunture)을 이용하여 타액의 분 비를 자극하려는 연구도 제한적으로 시도되고 있다. ${ }^{32}$

두경부 영역에 방사선 치료를 받는 환자는 세기조절 방사선 치료(intensity-modified radiation therapy)를 받아 타액선을 방사선 조사로부터 보호하려는 노력을 기울이기도 하고, 방사 선 조사 전 타액선 세포 보호제인 아미포스틴(amifostine) 등 의 약물을 사용해 볼 수 있다. 최근에는 줄기세포나 성장인자, 천연 항산화인자 등을 이용하여 구강건조증을 치료하고자 하 는 많은 노력들이 진행 중에 있다. ${ }^{33-35)}$

구강건조증의 치료로 환자의 생활습관의 변경 및 예방도 주요하다. 실내에서는 늘 가습기를 사용(특히 밤에 잘 때)하 고, 구강의 건조함을 증가시키고 탈수를 유발하는 음식(마른 음식, 산성인 음식, 카페인이 첨가된 음식, 알콜이 첨가된 음 료)은 피하는 것이 좋다. 또한 치과적 검진이나 구강 검진을 6 개월마다 정기적으로 하는 것이 합병증 예방에 도움이 된다. 충치를 예방하고 구강의 위생을 위해서는 당이 적은 식사를 하고 정기적으로 불소를 사용하는 것이 권장된다. 불소의 사 용은 타액분비 저하로 인한 충치를 예방할 수 있는 가장 효과 적인 수단이다. 구강의 곰팡이 감염은 구강건조증 환자에게 흔한 합병증 중의 하나이다. 린스, 연고, 사탕, 정제, 입안헹굼 제 등으로 만든 다양한 항진균제제를 사용할 수 있다. 구강의 항진균 치료에 반응이 없는 면역력이 떨어진 환자의 경우 전신 적인 항진균 치료가 필요할 수 있다. 틀니를 사용하는 구강건 조증 환자는 곰팡이가 자라지 않도록 매일 틀니를 소독해야 한다. 또한 당뇨나 신부전, 자가면역질환 등의 환자가 않고 있 는 기저질환을 잘 치료하는 것도 중요하다. 이는 증상을 경감 하고 악화를 방지하고 구강의 상태를 호전시키고 타액선의 기 능을 향상과 전신질환을 유지하는 데 도움을 준다.

\section{결 론}

구강건조증과 타액분비저하증은 많은 환자에게 불편감을 주는 질환이다. 본 논문에서는 구강건조증과 타액분비저하증 에 대한 진단 및 치료에 대해 요약하였다. 적절한 진단과 타액 선 기능의 상태를 평가하는 것은 적절한 치료법을 선택하고 증상을 개선시키고, 구강의 합병증을 예방하는 데 필수적이므 로, 환자의 주관적인 증상을 객관적인 타액선 기능저하와 감 별하고 치료하기 위해서는 보다 체계적인 접근이 필요하다. 비 록 정형화된 표준치료의 방법은 없지만 구강건조증을 접하는 의사들은 소개된 다양한 치료법들을 환자의 상황에 맞추어 
접목시키려는 노력이 필요하다.

\section{REFERENCES}

1) Hopcraft MS, Tan C. Xerostomia: an update for clinicians. Aust Dent J 2010;55(3):238-44; quiz 353.

2) van der Putten GJ, Brand HS, Schols JM, de Baat C. The diagnostic suitability of a xerostomia questionnaire and the association between xerostomia, hyposalivation and medication use in a group of nursing home residents. Clin Oral Investig 2011;15(2):185-92.

3) Pedersen AM, Bardow A, Jensen SB, Nauntofte B. Saliva and gastrointestinal functions of taste, mastication, swallowing and digestion. Oral Dis 2002;8(3):117-29.

4) Dawes C. How much saliva is enough for avoidance of xerostomia? Caries Res 2004;38(3):236-40.

5) Villa A, Polimeni A, Strohmenger L, Cicciù D, Gherlone E, Abati S. Dental patients' self-reports of xerostomia and associated risk factors. J Am Dent Assoc 2011;142(7):811-6.

6) Terpenning MS, Taylor GW, Lopatin DE, Kerr CK, Dominguez BL, Loesche WJ. Aspiration pneumonia: dental and oral risk factors in an older veteran population. J Am Geriatr Soc 2001;49(5):557-63.

7) Orellana MF, Lagravère MO, Boychuk DG, Major PW, Flores-Mir C. Prevalence of xerostomia in population-based samples: a systematic review. J Public Health Dent 2006;66(2):152-8.

8) Ship JA, Pillemer SR, Baum BJ. Xerostomia and the geriatric patient. J Am Geriatr Soc 2002;50(3):535-43.

9) Fox PC. Autoimmune diseases and Sjogren's syndrome: an autoimmune exocrinopathy. Ann N Y Acad Sci 2007;1098:15-21.

10) Shiboski CH, Hodgson TA, Ship JA, Schiødt M. Management of salivary hypofunction during and after radiotherapy. Oral Surg Oral Med Oral Pathol Oral Radiol Endod 2007;103 Suppl:S66.el-19.

11) Napeñas JJ, Brennan MT, Fox PC. Diagnosis and treatment of xerostomia(dry mouth). Odontology 2009;97(2):76-83.

12) Fox PC, Busch KA, Baum BJ. Subjective reports of xerostomia and objective measures of salivary gland performance. J Am Dent Assoc 1987;115(4):581-4.

13) Sreebny LM, Valdini A. Xerostomia. Part I: Relationship to other oral symptoms and salivary gland hypofunction. Oral Surg Oral Med Oral Pathol 1988;66(4):451-8.

14) Singh ML, Papas A. Oral implications of polypharmacy in the elderly. Dent Clin North Am 2014;58(4):783-96.

15) Smidt D, Torpet LA, Nauntofte B, Heegaard KM, Pedersen AM. Associations between labial and whole salivary flow rates, systemic diseases and medications in a sample of older people. Community Dent Oral Epidemiol 2010;38(5):422-35.

16) Osailan S, Pramanik R, Shirodaria S, Challacombe SJ, Proctor GB. Investigating the relationship between hyposalivation and mucosal wetness. Oral Dis 2011;17(1):109-14.

17) Eliasson L, Carlén A. An update on minor salivary gland secretions. Eur J Oral Sci 2010;118(5):435-42.

18) Choi JS, Lim HG, Kim YM, Lim MK, Lee HY, Lim JY. Usefulness of magnetic resonance sialography for the evaluation of radioactive iodine-induced sialadenitis. Ann Surg Oncol 2015;22 Suppl 3:S100713.

19) Hwang JH, Ahn HJ, Choi JS, Lee HY, Lim JY. Usefulness of magnetic resonance sialography for diagnosis of idiopathic chronic sialadenitis. Korean J Otorhinolaryngol-Head Neck Surg 2016;59(1): 41-8.
20) Visvanathan V, Nix P. Managing the patient presenting with xerostomia: a review. Int J Clin Pract 2010;64(3):404-7.

21) Aframian DJ, Helcer M, Livni D, Robinson SD, Markitziu A, Nadler C. Pilocarpine treatment in a mixed cohort of xerostomic patients. Oral Dis 2007;13(1):88-92.

22) Braga MA, Tarzia O, Bergamaschi CC, Santos FA, Andrade ED, Groppo FC. Comparison of the effects of pilocarpine and cevimeline on salivary flow. Int J Dent Hyg 2009;7(2):126-30.

23) Bernardi R, Perin C, Becker FL, Ramos GZ, Gheno GZ, Lopes LR, et al. Effect of pilocarpine mouthwash on salivary flow. Braz J Med Biol Res 2002;35(1):105-10.

24) Hamada T, Nakane T, Kimura T, Arisawa K, Yoneda K, Yamamoto T, et al. Treatment of xerostomia with the bile secretion-stimulating drug anethole trithione: a clinical trial. Am J Med Sci 1999;318(3):146-51.

25) Gómez-Moreno G, Guardia J, Aguilar-Salvatierra A, Cabrera-Ayala M, Maté-Sánchez de-Val JE, Calvo-Guirado JL. Effectiveness of malic acid $1 \%$ in patients with xerostomia induced by antihypertensive drugs. Med Oral Patol Oral Cir Bucal 2013;18(1):e49-55.

26) Gómez-Moreno G, Aguilar-Salvatierra A, Guardia J, Uribe-Marioni A, Cabrera-Ayala M, Delgado-Ruiz RA, et al. The efficacy of a topical sialogogue spray containing $1 \%$ malic acid in patients with antidepressant-induced dry mouth: a double-blind, randomized clinical trial. Depress Anxiety 2013;30(2):137-42.

27) Mouly SJ, Orler JB, Tillet Y, Coudert AC, Oberli F, Preshaw P, et al. Efficacy of a new oral lubricant solution in the management of psychotropic drug-induced xerostomia: a randomized controlled trial. J Clin Psychopharmacol 2007;27(5):437-43.

28) Regelink G, Vissink A, Reintsema H, Nauta JM. Efficacy of a synthetic polymer saliva substitute in reducing oral complaints of patients suffering from irradiation-induced xerostomia. Quintessence Int 1998;29(6):383-8.

29) Azodo CC, Ezeja EB, Omoaregba JO, James BO. Oral health of psychiatric patients: the nurse's perspective. Int J Dent Hyg 2012; 10(4):245-9.

30) Strietzel FP, Lafaurie GI, Mendoza GR, Alajbeg I, Pejda S, Vuletić L, et al. Efficacy and safety of an intraoral electrostimulation device for xerostomia relief: a multicenter, randomized trial. Arthritis Rheum 2011;63(1):180-90.

31) Alajbeg I, Falcão DP, Tran SD, Martín-Granizo R, Lafaurie GI, Matranga $\mathrm{D}$, et al. Intraoral electrostimulator for xerostomia relief: a long-term, multicenter, open-label, uncontrolled, clinical trial. Oral Surg Oral Med Oral Pathol Oral Radiol 2012;113(6):773-81.

32) O'Sullivan EM, Higginson IJ. Clinical effectiveness and safety of acupuncture in the treatment of irradiation-induced xerostomia in patients with head and neck cancer: a systematic review. Acupunct Med 2010;28(4):191-9.

33) An HY, Shin HS, Choi JS, Kim HJ, Lim JY, Kim YM. Adipose mesenchymal stem cell secretome modulated in hypoxia for remodeling of radiation-induced salivary gland damage. PLoS One 2015;10(11):e0141862.

34) Lim JY, Ra JC, Shin IS, Jang YH, An HY, Choi JS, et al. Systemic transplantation of human adipose tissue-derived mesenchymal stem cells for the regeneration of irradiation-induced salivary gland damage. PLoS One 2013;8(8):e71167.

35) Noaparast Z, Hosseinimehr SJ. Radioprotective agents for the prevention of side effects induced by radioiodine-131 therapy. Future Oncol 2013;9(8):1145-59. 